\title{
Transitivity of Sensory Verb in Indonesian
}

\author{
M Yusdi ${ }^{1}$, Lindawati ${ }^{2}$ \\ \{ ${ }^{1}$ muhammad_yusdi@yahoo.co.id, ${ }^{2}$ lindawatisaun@hum.unand.ac.id \} \\ ${ }^{1,2}$ Universitas Andalas, Indonesia
}

\begin{abstract}
This paper discusses the transitivity of sensory verb in Indonesian. This verb is sufficiently productive and analytical in its morphological process. The structural approach is used as to explain the transitivity of sensory verb in Indonesian. This research is conducted under three methodological procedures. They are a. collecting data, b. analyzing data, and c. displaying the result of the data analysis. The distributional method is used to analyze the data. On the data collecting, the method used is observational technique whereas in analyzing the data, the method used is distributional one using grammatical test, and the result of the analysis is presented using both informal and formal method. Owing to the research already done, thus, it was found that the sensory verb in Indonesian may undergo various morphological processes. Such morphological processes bring about implication to both categorical change and grammatical functions. Focusing upon the verbal features of sensory verb in Indonesian, it seems that Indonesian belongs to agglutinative language. This might be proved that 1 . Indonesian is an affixed language, 2 . The affix could be segmented with an obvious boundary of free morpheme and bound one, and 3. The morphological process on the verb brings about the change of grammatical relation or the verb transitivity that is prefix Vtr. + ma- in which $m a$ - 'nominativeaccusative', suffix verb Vtr. - ( $k$ )an 'causative', and prefix Vtr. di- 'passive'
\end{abstract}

Keywords: Verb, Transitive, Intransitive, Syntax, Semantics

\section{INTRODUCTION}

The language may be considered as an organ comprising of elements. They are systematically organized and one of which there is a functional relationship. Thus, language may be accounted for a system. As a system it preserves three sub-systems those are phonological, morphological or grammatical, and lexical ones. The grammatical sub-system is divided into morphological and syntactic ones. Morphological subsystem consists of word and its parts and its formation process. The syntactic one comprises word and the larger units the word itself as well as the inter-relation among them.

Langacker [1] said that a grammatical construction is a combination of an integrated symbolic structure between two or more components manifested in both semantic and phonological structures. Referred to the definition proposed, as seen from the form, the grammatical construction may refer to an arrangement in form of a word consisting of two or more morphemes in a form of phrase consisting of two words ore more that is a clause. Each grammatical construction has a component either verb, noun, or the other syntactic category. The prominent or the eyes catching part of which could be verb or noun present in a clause.

Both Ungerer and Schmidt [2] stated that verbal choice used in a clause could become a frame defining factor. They gave the example as verb to buy in a sentence like David bought an old shirt from John for ten Pounds. The verb bought becomes a forming frame knowledge structure constituted from a scheme or a wit obtained daily. So far, the frame constituted from 
the verb to buy is the one having money that is buyer so that s/he can buy. The constituent seller 'the one having goods wanted by the buyer is purchases and sold, and money is a legal tender to purchase. Both Ungerer and Schmidt [2] said that the verb to buy in such an example becomes a defining part in the clause at which it is used to constitute the frame.

As to discuss the transitivity of sensory verb in Indonesian, hereinafter, abbreviated to as Bahasa Indonesia (BI) in a scope in form of a clause. The state of being a verb may be proved from how it behaves syntactically in a larger unit whether it is a clause or a phrase. Phraseologically, a word in BI can be said that it belongs to a verbal category as it can be preceded by a negative constituent tidak 'not' [3]. Syntactically, the word belonging to a verbal category could occupy the predicate function in a clause. Primarily, a clause is potentially to become a basic sentence. The basic sentence is the one of declarative, simple, affirmative (no negation), non-sytilistic (no methaphore), and syntactically SPO ordered [4]. A sentence is a linguistic unit relatively could stand independently, preserve an intonation, and consists of a clause. A clause is a syntactic unit built up of both subject and predicates constituents. Subject is a clausal constituent stating what the clause is about. Just take one sufficiently productive sensory verb in use and with creative form for discussion that is the verb melihat 'to see'.

\section{RESEARCH METHOD}

The verb of BI written by Kridalaksana [3] is formally distinguished from freely basic verb and derived one. It means before it undergo a morphological process, it already belongs to the verbal category, for example, ambil 'to take', beri 'to give', bawa 'to bring, beli, to buy', cari 'to seek', cium 'to kiss', coba 'to try', cicip 'to taste', datang 'to come', dengar 'to hear', duduk 'to sit', goreng 'to fry, hitung 'to count', jemput 'to pick up', kuras 'to drain', lawan 'to defy', lecut 'to whip', lihat 'to see', makan 'to eat', minum 'to drink', mandi 'to bathe', tunggu 'to wait', panggil 'to call', pegang 'to hold', pergi 'to go', pulang 'to go home', pakai 'to wear', pukul 'to beat', raba 'to fumble', rekam'to record', rendam 'to immerse', rebus 'to boil', tidur 'to sleep', tanya 'to quest', tolong 'to help', tangkap 'to catch', terbang 'to fly', tutup 'to shut', ulang 'to repeat', urus 'to handle', and ukur 'measure'.

The derived verb that is the one constituted from a free morpheme undergoing a morphological process whether affixation or reduplication, the affix attach to the basic word could be in forms of prefix, infix, or suffix, as well as confix. The Indonesian affixes may be attached to various word classes regardless noun, verb, adjective, number, and functor all of them constitute derived verbs among other, for instance, menuhankan 'to treat as God', meninggikan 'to heighten', mendatangkan 'to cause to came', menduakan 'to make two', meniadakan 'to annul'.

Since the title of our discussion is the transitivity of sensory verb in BI, thus, what becomes the object is Indonesian syntax in Its Construction Found Sensory Verb Mainly lihat 'to see' with its various derivations. Regarding the grammatical subject, in relation to the verb becoming predicate in a basic clause it refers to verbal diathesis. The diathesis is related to how to express a proposition and there discussed if the grammatical subject plays a role as a doer or not of an action stated by the transitive verb of the predicate. Jufrizal [5], and Yusdi [4] there are three diatheses in all languages. Thus, the diathesis derives voices. Such three voices refer to Shibatani [6], Kulikov [7], and Vater [8].

Nominative-Accusative derive active and passive voices. The active subject is the agent that affects the patient that the object of the active voice is in a given state (suffering). In BI, the active voice is morpho-syntactically marked paraphrastically S-Pvtr+-me-O. E.g., Tarman menendang Randa. 


\section{tarman ACC kick randa \\ 'Tarman kicked Randa.'}

The action occurs under the control of subject. It means that on one hand the subject must be a human and the one, in a passive clause, the grammatical subject play a role as the undergoer (experiencer) of the activity done by the agent, and morphosyntactically marked paraphrastically marked S-Pvtr+di-. E,g. Tarman di-tendang (Randa)

tarman PASS kick (by Randa)

'Tarman was kicked (by Randa).

Ergative-Absolutive derives ergative and anti-passive voices. Ergative clause is the one whose subject is also an agent but it cannot be passivized due to morphological constraint (morphologically unmarked). E.g. Saya beli buku itu. (ERG)

1 SG bought book ART

'I bought the book.'

Saya lahir 50 tahun lalu.

$1 \mathrm{SG}$ born 50 years ago

'I was born 50 years ago.

However, the absolutive one may define a clausal construction in which the object of transitive verb is the same as the subject of the intransitive one. E.g.

Tombakitu me-nembus dada-nya. (NOM-ACC)

spear ART ACC penetrated chest 3SG POSS

The spear penetrated his chest.

The sentence above may be translated into

Dada-nya di- tembus oleh tombak. (PASS)

chest 3SG POSS PASS penetrated by spear

'His chest was penetrated by a spear.'

Dada-nya tembus (oleh tombak.) (ERG-ABS)

chest 3SG POSS penetrated (by a spear)

'His chest is penetrated (by a spear.)'

Diathesis of Middle voice derives three voices [9], [10]. This may be interpreted that the action done by the subject affect the subject itself. There are three forms of middle voice those are:

Rahman mandi. (Lexical)

rahman took a bath

'Rahman took a bath.' 
Ali ber-lari. (Morphological)

ali pre- lari

'Ali ran.'

Ali me- lari -kan diri. (Paraphrastic)

ali ACC ran CAU self

Ali escaped.

Dealing with a transitivity, the verb occupying the predicate function of a clause is concentrated upon its subject role so that it results is the presence of terms active-passive, ergative-absolutive, and middle voice [4].

\section{RESULT AND DISCUSION}

The word lihat 'to see' is one of sensory verbs in BI my undergo various morphological processes such as reduplication, collocation, and affixation [11]-[13]. The derived form is among others lihat, melihat, lihati, lihatkan, melihati, melihatkan, dilihati, dilihatkan, kelihatan, terlihat, penglihatan, lihat-lihat, lihat-melihati, lihat-menglihatkan, saling lihat, lihat dulu, lihat saja, etc. The word lihat 'to see' with all of its derivations may occupy the predicative function. Each of the verbal form will result in various possibilities of sentences that can be built. Each form has different valences. Herein the valence is meant as a number of nouns required by the verb. Noun or noun phrase appears after the verb may be as object, complement, or adjunct. The different number of nouns required by the verb signify the level of transitivity of the verbs. Transitivity is a verb character defining whether in a clausal construction there found a noun functioning as an object [14]-[17]. The word lihat 'to see' as a basic word and its derivations, if it occupies predicative function, it will have a capacity to bind different nouns. Look at the following examples:

(1) a. Saya lihat peristiwa itu. Nom/Aku

'I show the ivent.'

b. Saya melihat anak itu di pasar. Nom/Aku

'I show the children at the market place.'

c. Lihatkan saja padanya!

Just show him'

d. Dia melihati saya dengan curiga.

He looks at me suspeciously'

e. Rangga melihatkan rapornya pada saya.

Rangga show his raport to me.'

f. Rumah itu dilihatnya dari jauh saja Pasif

'The house was seen by him from faraway.'

g. Kami dilihatinya dari jauh

'We were seen by him from fareway'

h. Cincin pernikahan itu dilihatkannya/diperlihatkannya kepada saya.

'The wedding ring was shown by him to me.'

i. Dia memperlihatkan buku nikahnya kepada saya. Nom/Aku

'He show his merry certificate.'

j. Dia kelihatannya baik-baik saja. Erg/Abs

'He look well.' 
k. Penglihatan sudah kabur.

'His sight is blurr.

1. Dia terlihat sehat. Erg/Abs

'He look healthy.'

m. Kami hanya lihat-lihat saja.

'We just look around.'

n. Kami melihat-lihat barang antik yang dipajang di galeri itu. Nom/Aku

'We show antique thing at the gallery.'

The verb lihat 'to see' and its derivations have different syntactic behavior because each form has different valence. Herein, the valence means as the number of nouns the verb needs ia single clause. A noun or a noun phrases appears after the verb may be functioning as an object, a complement, or an adverb. The different number of nouns required by a verb signifies that the verbs have different transitivity. Transitivity is a verbal character that will define if in a clausal construction there found a noun functioning as an object. The word lihat 'to see' as the basic word and its derivations, if it occupy a predicative function will be able to bind different nouns. Look at the following examples.

(2) a. Saya melihatnya.

'I show him.'

b. Saya melihatnya di pasar.

I show him at the market place.

c. Saya melihatnya kemaren.

'I show him yesterday.'

d. Saya melihatnya dengan mata kepala sendiri.

'I show him by my own eyes.'

e. Saya melihat (hanya) dari jauh.

'I show him just from away.'

f. Dia melihat ke/kepada kami. Nom/Aku

'He look at us.'

All sentences in group two are seen that more sentences could be formed with a verb melihat 'to see'. The word melihat 'to see'is a verb stating an activity done by human being. The verb melihat 'to see' is a transitive one. The must be something that is seen and this is the object. In example (2) the noun occupying the subject function plays a role of the agent/the actor. Therefore, the sentences in (2) are referred to as active voice. As the activity, of course it is done by human or animate at a given time and place. The word after verb melihat 'to see' that is non object function as adjunct.

The passive clause is derived from active one and morphologically marked. In Indonesian, both active and passive clauses are cannonically and syntactically marked with S Pvtr+me- >< S Pvtr +di-. So significant is the the morphological process to the verb that there occurs syntactic and semantic features of the words.

(3) Rumah itu di- lihat -nya dari jauh. house ART PASS 3SG AGN from far away

'The was seen by him from far away.' 
The verb terlihat 'can be seen' belongs to ergative. The sentences in group (4) are not passive clauses though the nouns functioning as subjects are not actors but somethings affected by the action (undergoer). Semantically, the sentence (4) is is the same as the following passive.

(4) Rumah itu terlihat dari sini. Erg/Abs

'The house was seen from here.

The verb lihatkan, melihatkan or memperlihatkan 'show' belongs to causative'.

(5) a. Lihatkan rapormu pada saya.

'Show me your raport!'

b. Rahman melihatkan/memperlihatkan rapornya pada saya.

'Rahman show his raport to me.'

Many sentences that can be constructed with the verb lihat 'to see'. This is due to the syntactic and semantic characteristics of the word lihat 'to see' it self. The word lihat 'to see' is the verb stating an activity done by a human. Of course, as an activity, is done in a given time and place. In doing the activity lihat 'to see', some times somebody uses a certain tool or a means. Such an activity may be done together, it is done at a given time, place, purpose, reason. This causes various component could get involved either before or after the verb lihat 'to see'. Look at the following examples

(6) a. Saya lihat.

'I see.'

b. Saya bisa lihat.

'I can see.'

c. Saya sudah lihat.

'I have seen.'

d. Saya akan lihat.

'I will see.'

e. Saya pernah lihat.

'I ever saw.'

f. Saya lihat dengan mikroskop.

'I see it with a microscope.'

g. Saya lihat kemaren.

'I saw it yesterday.'

h. Saya lihat di luar negeri.

'I saw it abroad.'

h. Saya lihat juga.

'I see it too.'

i. Kami lihat bersama-sama kemaren.

'We saw it together yesterday.'

j. Saya lihat dengan mata kepala sendiri.

'I saw it with my owen eyes.'

k. Saya lihat untuk memastikan berita yang saya dengar.

'I saw it to make sure what I heard.' 


\section{CONCLUSIONS}

Considering the behavior of verb lihat 'to see' in BI above, morphologically, the Indonesian belongs to agglutinative language. This is proved for BI has affix, affix can be clearly separated from the basic word because it has a clear morphemic boundary, the verbal morphological process causes the change of the grammatical relation.

The morphological presence causes the change in the case of grammatical structure, semantic role, argument structure, verbal transitivity.

\section{ACKNOWLEDGEMENT}

The author expresses gratitude to Lembaga Penelitian dan Pengabdian kepada Masyarakat Universitas Andalas and Program Studi Sastra Minangkabau Universitas Andalas.

\section{REFERENCES}

[1] R. W. Langacker, Cognitive Grammar: A Basic Introduction. Oxford: Oxford University Press, 2008.

[2] F. Ungerer and H.-J. Schmid, An introduction to Cognitive Linguistics. Longman, 1996.

[3] H. Kridalaksana, Kelas Kata dalam Bahasa Indonesia. Jakarta: Gramedia, 1986.

[4] M. Yusdi, Relasi Gramatikal dalam bahasa Melayu Klasik: Tinjauan Tipologi Sintaksis. Padang: Minangkabau Press, 2013.

[5] Jufrizal, Tatabahasa Bahasa Minangkabau: Deskripsi dan Telaah Tipologi Linguistik. Padang: UNP Press, 2012.

[6] M. Shibatani, "On the conceptual framework for voice phenomena," Linguistics, vol. 44, no. 2, pp. 217-269, 2006.

[7] L. Kulikov, "VOICE TYPOLOGY," in The Oxford Handbook of Linguistic Typology, J. J. Song, Ed. Oxford: Oxford University Press, 2012.

[8] L. I. Kulikov and H. Vater, "Typology of verbal categories," in Linguistische Arbeiten, 1998, p. 310.

[9] A. Deda and L. Lumezi, "The Traditional Conception of Diathesis (Voice) and a Modern View to It," European Journal of Language and Literature Studies, vol. 1, no. $1,2015$.

[10] A. Alexiadou, "Active, middle, and passive: the morpho-syntax of Voice," Catalan Journal of Linguistics, vol. 13, pp. 19-40, 2014.

[11] A. Alexiadou, "On the role of syntactic locality in morphological processes : the case of ( Greek ) derived nominals," in QP structure, Nominalizations and the role of DP, 2005.

[12] R. S. Kruk and K. Bergman, "The reciprocal relations between morphological processes and reading," Journal of Experimental Child Psychology, vol. 114, no. 1, pp. 10-34, Jan. 2013.

[13] T. Nunes, P. Bryant, and M. Bindman, "Morphological spelling strategies: Developmental stages and processes.," Developmental Psychology, vol. 33, no. 4, pp. 637-649, 1997.

[14] R. Ezzina, "Transitivity Analysis of «The Crying lot of 49 » by Thomas Pynchon," International Journal of Humanities and Cultural Studies (IJHCS) ISSN 2356-5926, vol. 2, no. 3, pp. 283-292, Mar. 2016.

[15] B. Ambridge, J. M. Pine, C. F. Rowland, and C. R. Young, "The effect of verb semantic class and verb frequency (entrenchment) on children's and adults' graded judgements 
of argument-structure overgeneralization errors," Cognition, vol. 106, no. 1, pp. 87129, Jan. 2008.

[16] K. Hale and J. Keyser, "Some transitivity alternations in English," Anuario del Seminario de Filología Vasca" Julio de Urquijo", vol. 20, no. 3, pp. 605-638, 1986.

[17] T. Lin, "Light Verb Syntax and the Theory of Phrase Structure," University Of California, California, 2001.

[18] K. Saddhono, "Language and superdiversity: Indonesians knowledging at home and abroad. By Zane Goebel." Soc. Stu. vol. 12 no.1 pp. 113-118, 2018 